\title{
The Role of Renewable Energy to Achieve Energy Sustainability in Iran. An Economic and Technical Analysis of the Hybrid Power System
}

\author{
A. Armin Razmjoo ${ }^{1} \cdot$ Afshin Davarpanah $^{2}$ (D) Amirhossein zargarian $^{3}$
}

Received: 25 July 2018 / Accepted: 15 March 2019 / Published online: 25 April 2019

(C) Springer Nature Singapore Pte Ltd. 2019

\begin{abstract}
The aim of this study is an economic and technical analysis of a hybrid system in the Semirom city of Iran that is performed by a technical-economic analysis on combined utilization of solar-wind and diesel system. In this study HOMER software is utilized for economic assessment and optimization. At first, the related meteorological data gathered and then using Homer software the calculation was carried out. This city has good potential for solar and wind energy. The solar radiation ranges of Semirom city is from 2.88 to $7.78 \mathrm{kWh} / \mathrm{m} 2 / \mathrm{d}$, and the wind speed ranges are from 2.9 to $5.3 \mathrm{~m} / \mathrm{s}$. Solar and wind analyses on Semirom show that this city have great potential in solar and wind energy generation because this city has a proper position to receive sun solar and has high potential in wind speed for wind power generation. Regarding this study and due to high potential in solar and wind energy in Semirom, investments on renewable energy sector of this city will be economically justified.
\end{abstract}

Keywords Energy sustainability $\cdot$ Renewable energy $\cdot$ Hybrid system $\cdot$ Technical-economic analysis

\section{Introduction}

The importance of energy is not cover on anyone because energy is a vital need for human future [39]. Also, owing to the rise in lifestyle facilities, is rapidly increasing the energy demand. On the other hand, the energy supply by fossil fuel that is main resources has a negative effect on our planets such as global warming and air pollution [7-9, 36, 38]. Hence one of the most important of proper policy to prevent these problems is move toward sustainable development especially in energy sustainability [31]. Thus, in order to reduce

Afshin Davarpanah

Afshin.Davarpanah@srbiau.ac.ir

1 Escolla Técnica Superior d'Enginyeria Industrial de Barcelona (ETSEIB), Universitat Politécnica de Catalunya (UPC), Av. Diagonal, 647, 08028 Barcelona, Spain

2 Department of Petroleum Engineering, Science and Research Branch, Islamic Azad University, Tehran, Iran

3 School of Engineering, University of South Australia, Mawson Lakes Campus, Mawson Lakes, South Australia 5095, Australia greenhouse gases emissions and environmental pollution in the line of energy sustainability, various solutions are recommended, that one of them is utilization renewable energy [23]. Nowadays, the use of renewable energies has become binding law in many countries around the world, and governments are proposing to replace renewable energy with fossil fuels [1, 3, 10-12]. Renewable energies are increasingly seen as demanding affordable access to electricity while reducing the need for fossil fuels [17]. Various types of renewable energies are used today to provide energy that is considered to be the most important wind and solar energy [9, 13, 16, 22, 26]. Wind turbines and solar panels play a significant role in supplying electricity around the world [21]. Renewable energies also play a significant role in sustainable urban development the concept of sustainable development can start from rural areas and cover the entire community [24]. Today, different countries around the world are struggling to develop sustainable urban development using renewable energy approach [4]. In the field of energy sustainability by renewable energy, many works have been performed that some of them could be mentioned. An analysis of energy sustainability by renewable energy by using multiple criteria decisionmaking method, investigated by Mardani A et al. [25]. 
Fig. 1 U.S. energy consumption by energy source, 2018

\section{U.S. energy consumption by energy source, 2017}

\section{Total $=97.7$ quadrillion \\ British thermal units (Btu)}

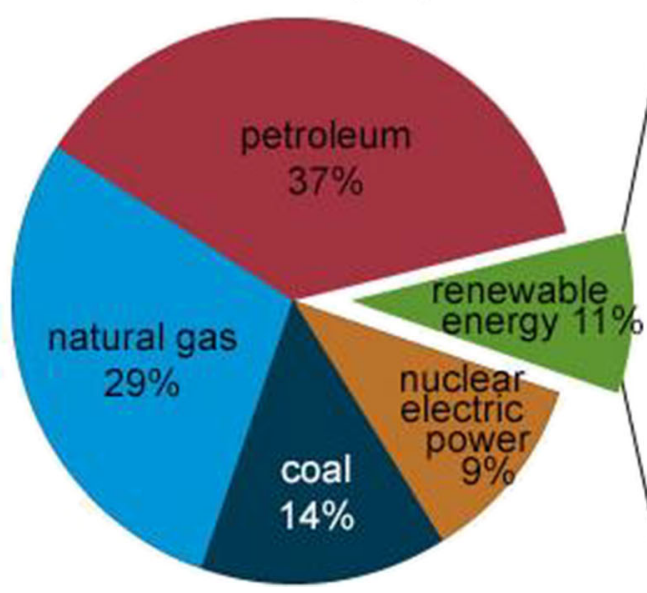

Total $=11.0$ quadrillion Btu

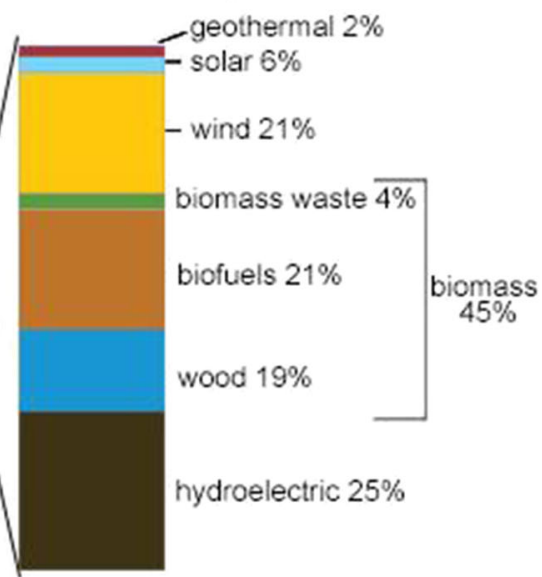

Ibrahim dincer et al. presented a crucial review related the importance of renewable energy to achieve sustainable development. He in this research emphasis that renewable energy moreover being a safe resource to energy supply are effective to reduce environmental problems [15]. Chauhan RK et al. for power losses optimization presented a study relation management of renewable energy source and battery bank. Indeed they in this study and for a DC micro-grid in grid-connected presented an intelligent control strategy that was effective for PV and multi-battery bank [5]. Mehdi Mehrpooya et al. investigated a techno-economic-environmental study of the hybrid power supply system for Iran country. They presented an optimal planning model to reduce a real load by PV-Diesel Generator-Battery hybrid system. Also, they considered the impact of diesel fuel price fluctuation on the economic competitiveness of suggested hybrid renewable energy systems in this study. Chu S, et al. in a study mentioned that one of the most important ways to achieve sustainable energy is renewable energy. They

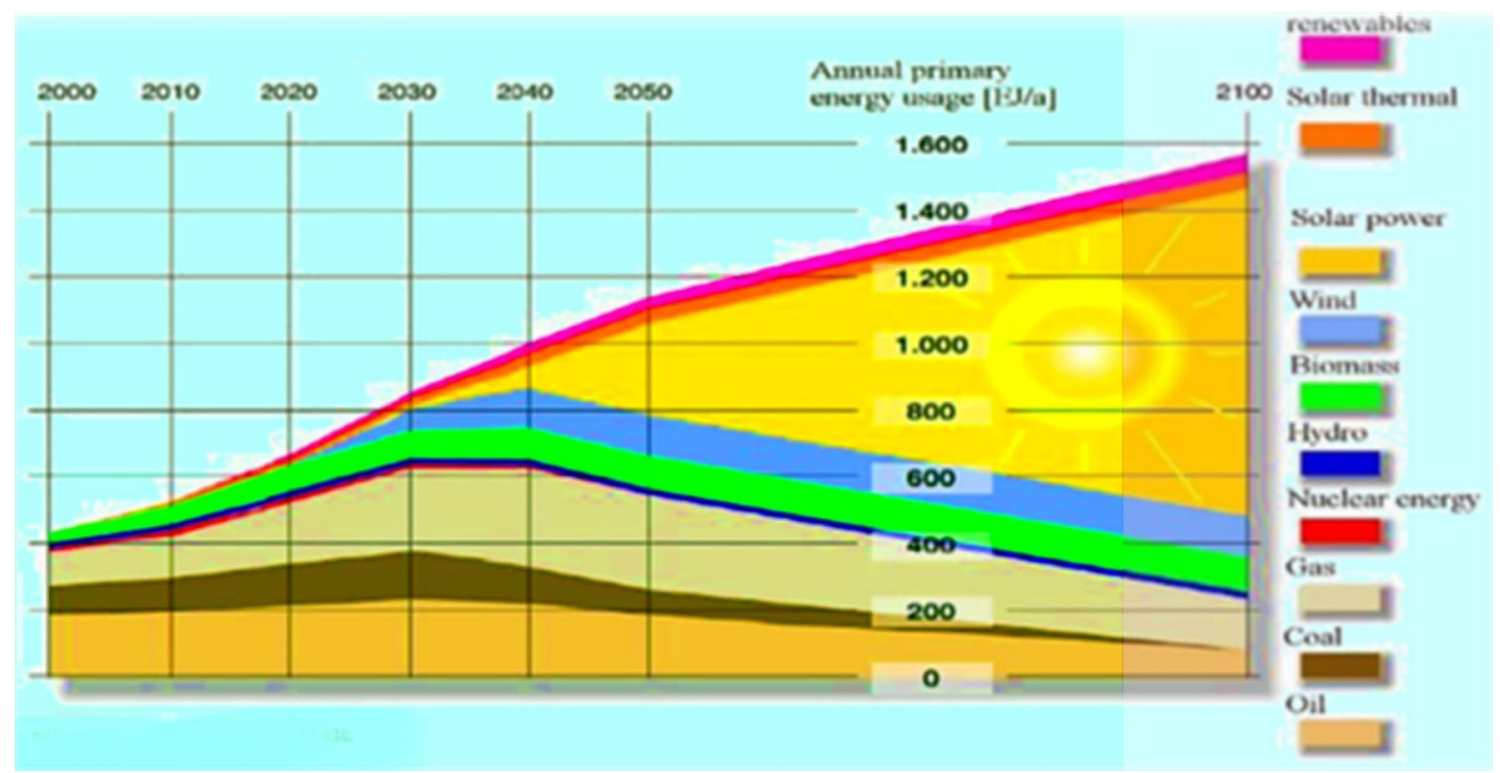

Fig. 2 Type of consumption energy of the word from 2000 to 2100 

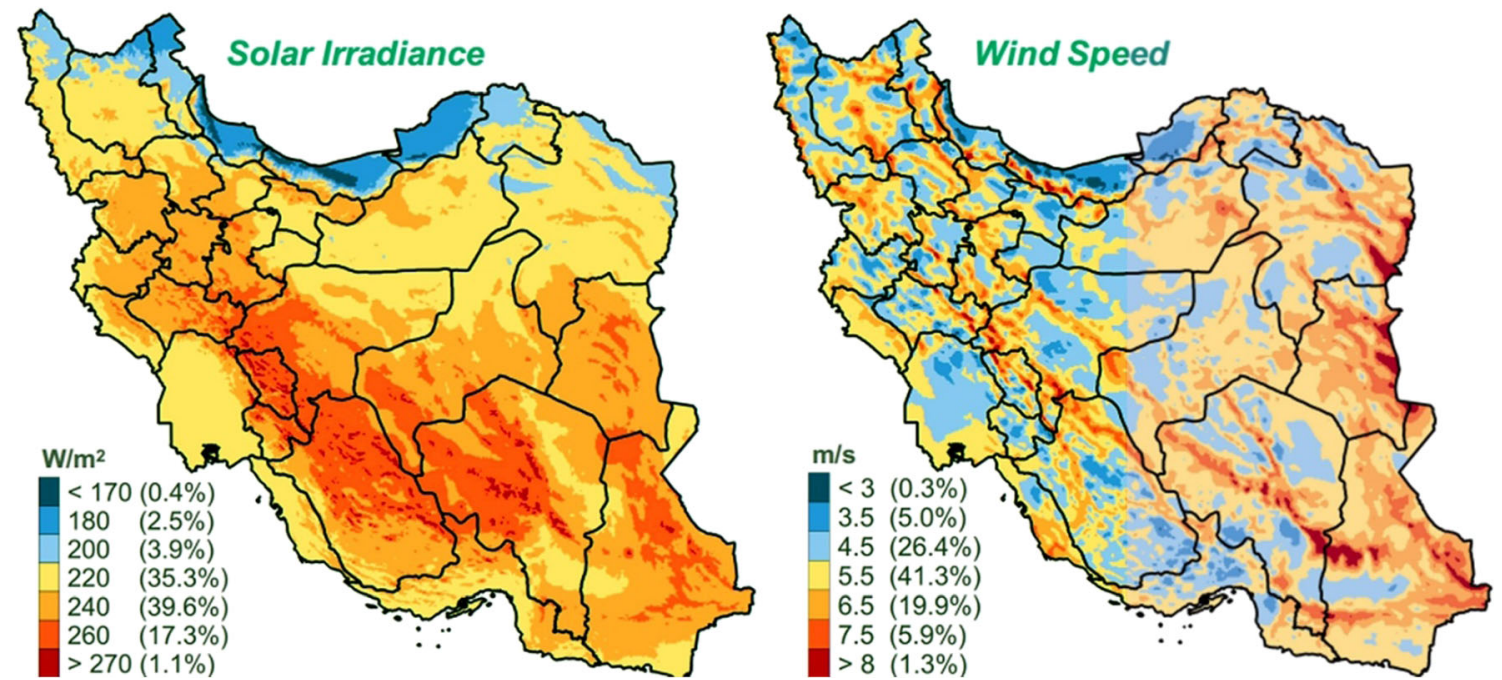

Fig. 3 The distribution of energy resources in Iran especially wind and solar potential [37]

also believed renewable energy also has many positive effects on the environment [6]. A study related Chauhan RK et al. had done demand-Side Management System for Autonomous DC Micro-grid for Building. In this research new demand-side management (DSM) scheme for the autonomous DC micro-grid for the future building proposed. This system also is investigated as a prospective system owing to the increase of DC loads and DC power sources. Also, this suggested scheme is capable of reducing the size of the PV plant, storage and capital cost of the system. Hadian S, et al. in a conceptual study investigated the different kind of green energies that are proper to energy sustainability. They in this research also surveyed the production processes of energy and effected it on economic, environmental, and social system [18]. Also a study about the process of energy production in Iran and its impact on sustainable development has been carried out by Tofigh AA et al. In this study has also been carried out and completed an analysis of energy Status in Iran for sustainable energy design roadmap and even research on the development of renewable energy in rural areas of Iran [37]. In this paper, has been considered the renewable energy potential of the Semirom city in Iran. Considering the high potential of solar and wind power in Semirom, and with technical

Table 1 Geographical coordinates of Semirom city

\begin{tabular}{llll}
\hline City & Longitude & Altitude & Elevation from the sea \\
\hline Semirom & 3124 & 5134 & 2400 \\
\hline
\end{tabular}

and economic calculations, it has been tried to encourage investment in renewable energy in the city.

\section{Hypothesis and Objectives of this Study}

This study has the following two main goals. First of all, it introduces a high potential city in Iran from the renewable energy view which can be suitable for investment in this regard and provide a part of the required energy to residential sectors. Second of all, this research trying show the benefits of renewable energy against fossil fuels for the future. Because since the fossil fuels are limited and are not permanent, hence regarding negative impacts it on the environment as far possible as should be used of renewable energy. However, main questions it is that how over time renewable energy can be replaced of fossil fuels in this area and other areas in Iran. To answer to this question should be said that still the price of fuel in Iran is lower than many countries and government and people of Iran prefer the use of fuel fossils that it is the main problem to less approach to renewable energy. Confidently can be said that for a country like Iran the importance of renewable energy still is not significant due to the mentioned reasons. However, all of policymakers and energy programs of Iran should be implementing the renewable energy projects for future rapidly. In this regard use of correct measurements such as for encouragement and support of renewable energy project even small projects, training people to more awareness of clean energy advantages and over time substitution renewable energy 


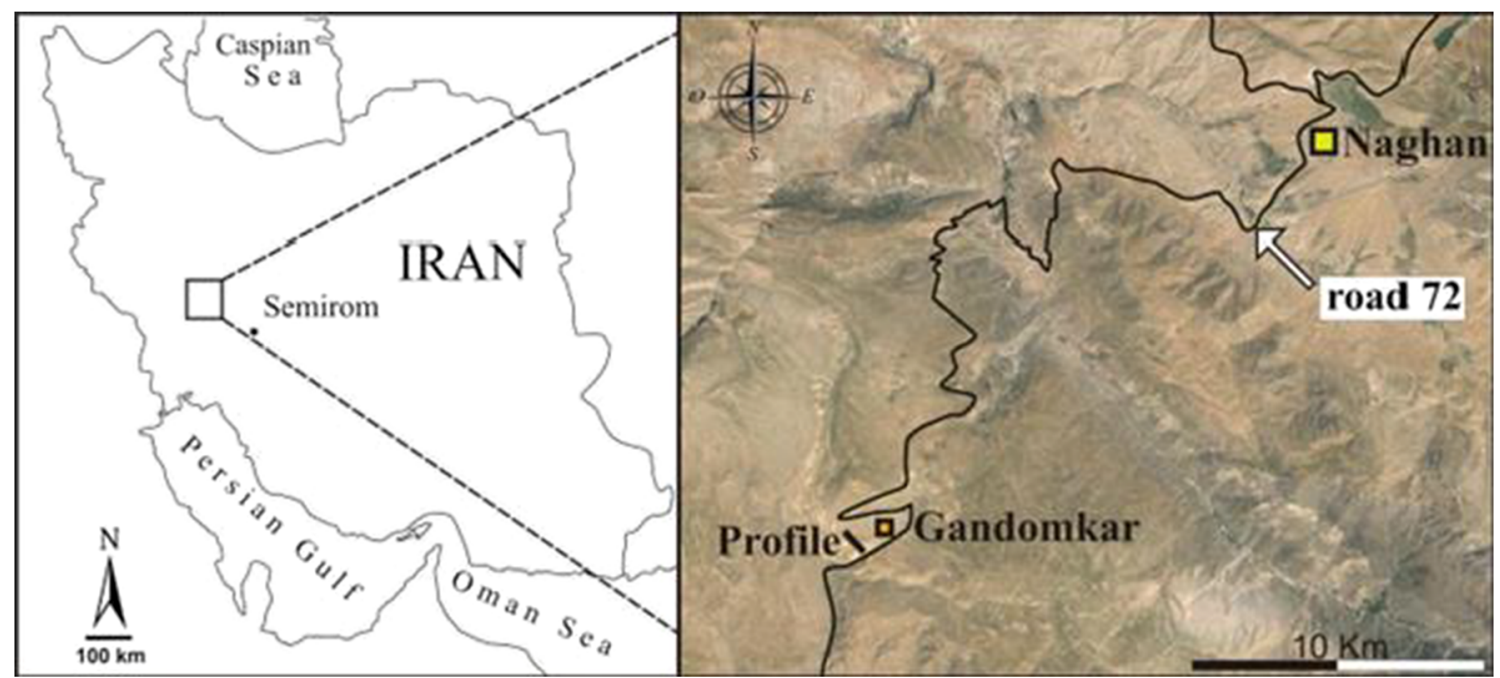

Fig. 4 Location zone studied on the map of Iran

instead of fossil fuels especially in high potential areas can be effective and feasible.

\section{Energy Supply by Solar and Wind Energy in the World}

Energy supply is one of the most important issues and needs of different countries in the world, especially the generation of electricity, which, if this work performed by fossil fuels which has many pollution and cost [30]. In this regard, the use of renewable energy such as wind and solar energy can both contribute to the supply of electricity and contribute significantly to the environment also the results of the research show that long-term solar and wind power plants can have economic justification [29]. Also, renewable energy is a reliable resource to provide a part of the energy in the future.

Figure 1 that is an analysis by U.S energy consumption shows the percent of each kind of energy in the 2018 year and as it is clear the renewable energy has
$11 \%$ of total consumption of energy in comparison with another kind of energy.

Also, Fig. 2 shows the type of consumption energy of the word from 2000 to the 2100 year based a projection. As can see the renewable energy will be a key role in energy supply in the future.

\section{World Potential of Solar and Wind Energy for Electrical Production}

Utilization of renewable energy today is one of the most appropriate ways of generating electricity [32]. Various countries with long-term planning and investment in renewable energy are trying to provide a significant portion of their future energy needs in the future [14]. Among renewable energies, the role of wind and solar energy is most remarkable for electrical production [40]. Because wind speed and solar radiation especially in the countries with proper potential in this regard are
Fig. 5 Daily profile of hourly electrical load for the residential building

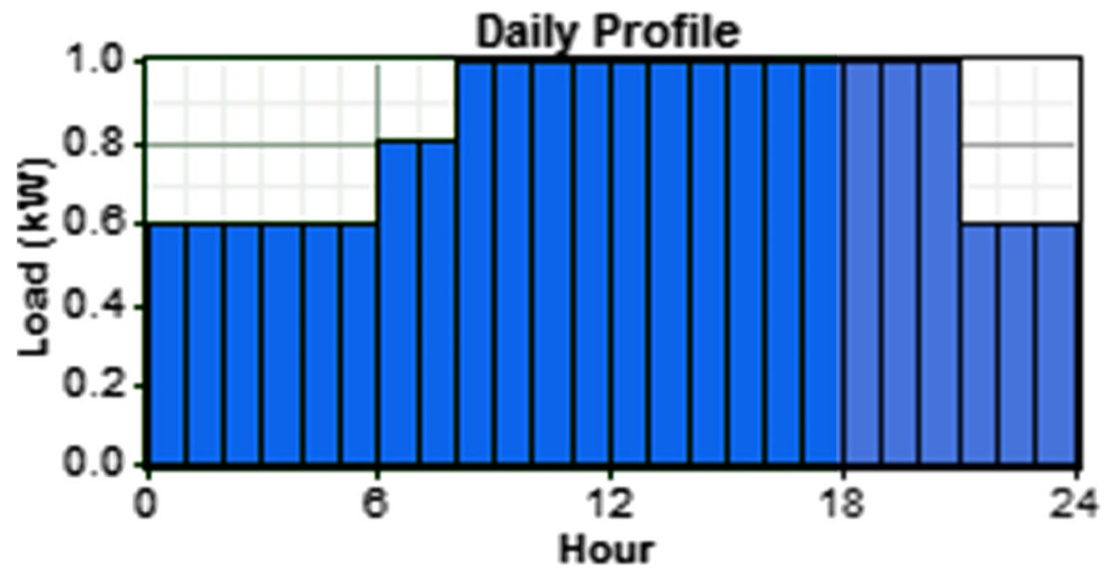


Fig. 6 Monthly wind speed of Semirom

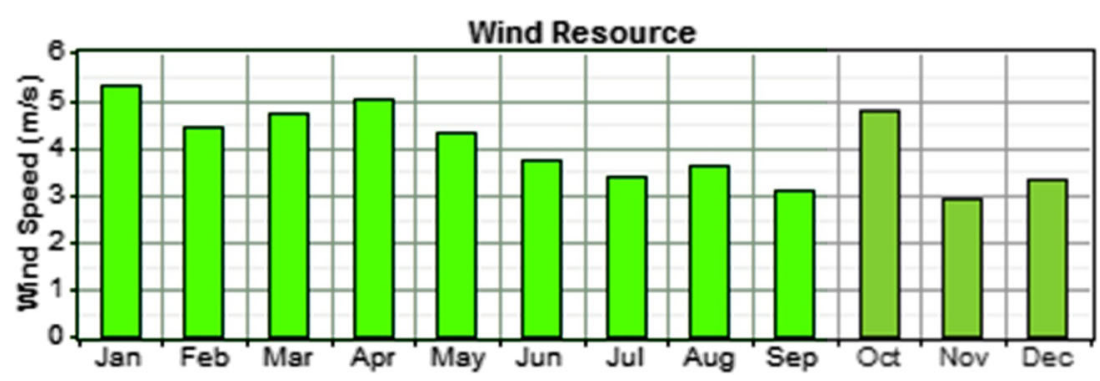

an effective factor to more exploitation of renewable energy and electrical production [34].

\section{Solar and Wind Energy Potential in Iran}

Iran country with an area of $1,648,195 \mathrm{~km}^{2}$ and a diverse climate has high potential in renewable energy especially in solar energy that can use of such area capacity to electricity production actually Iran's location on the Sun Belt means that it receives the highest level of solar radiation, which makes solar energy an ideal solution for its long-term energy needs [28]. More than two-thirds of Iran experience about 300 sunny days per year and average solar radiation of Iran is about 4.5-5.5 $\mathrm{kw} / \mathrm{m}^{2}$ per day, which points to a very high solar energy generation potential [20]. For example it can be mentioned that some of cities in Iran such as, Yazd [34], Taleghan, Abadan, Bandar-Abbas, Semnan [2], Kashan [33] has a good potential in solar energy. Also Iran country for good weather condition is suitable for wind energy utilization, and the abundance of windy areas in
Iran provides it with a suitable platform to extend the development of wind farms. Areas around Manjil in Gilan, Binalud in Khorasan and Zabul and Zehak in Sistan-Baluchistan province have a very high wind energy generation potential [35]. The potential energy of wind is estimated to be about $6500 \mathrm{MW}$ in Iran [27]. Figure 3 demonstrates the distribution of energy resources are exploited in Iran especially wind and solar potential.

\section{Case Studies}

In this paper, Semirom city in Esfahan province considered and in the following location, population, weather, etc., about them will be mentioned.

\section{Description Studied Area}

Semirom city is placed in the southwest of Isfahan province with an area of $5224 \mathrm{~km}^{2}$ and is near to three provinces of Chaharmahal and Bakhtiari, Kohgiluyeh and
Fig. 7 Monthly solar radiation potential of Semirom

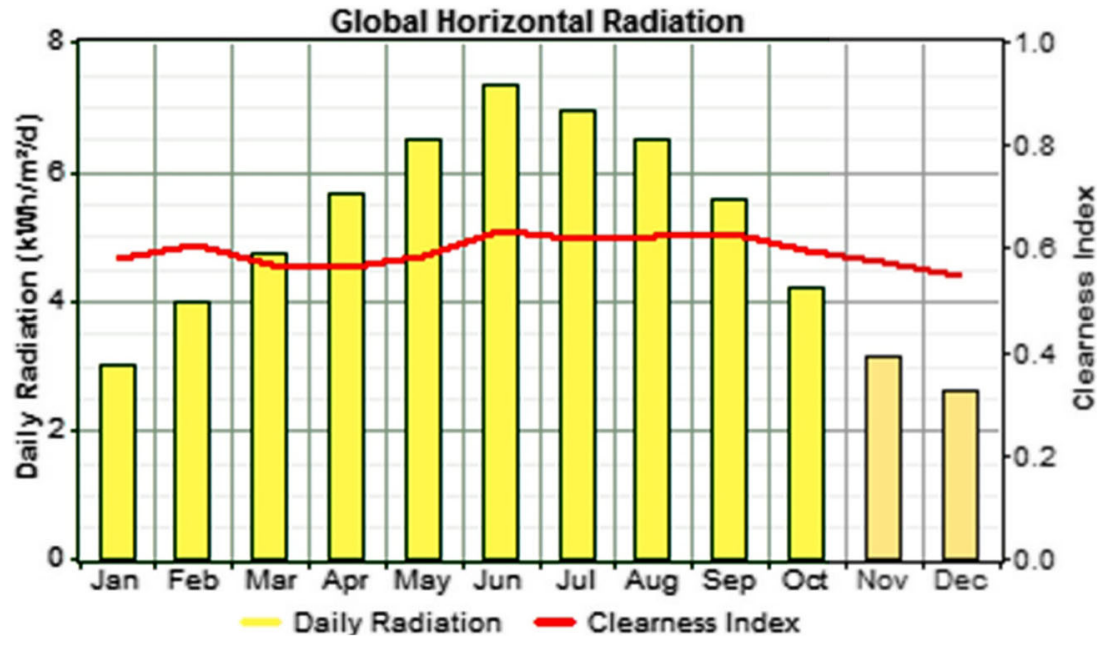


Fig. 8 Shows monthly wind speed and solar potential for Semirom city

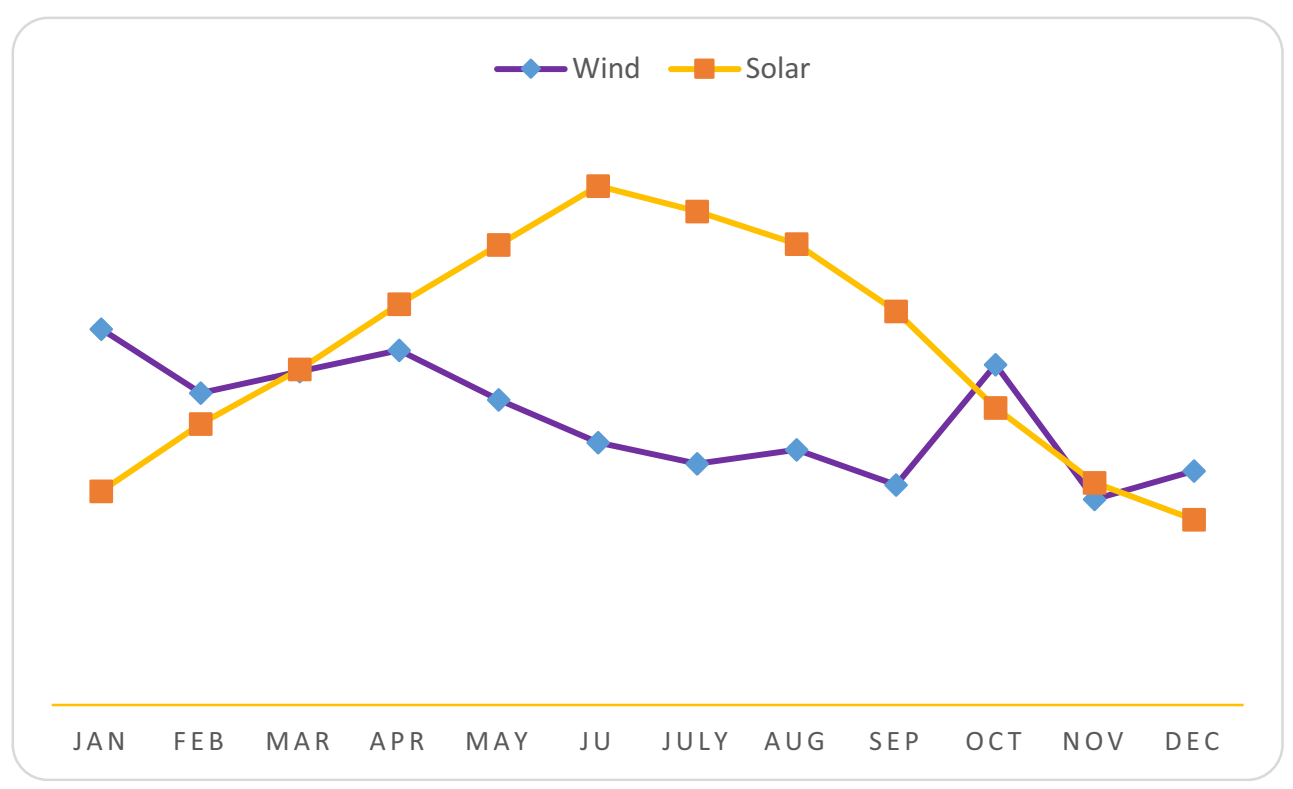

Boyer Ahmad and Fars. This city with Coordinates 3124 ' $\mathrm{N}$ and 5134 ' $\mathrm{E}$ and an average altitude of $2400 \mathrm{~m}$ above sea level at an altitude and is one of the tourist hubs of the province. The city of Semirom is considered the best city of Isfahan province regarding water resources and natural resources. This city has according to 2017 census 23,200 populations. It has a very cold winter and mild climate in summer. Table 1 shows the geographical coordinates of Semirom city.

Figure 4, shows the location zone studied on the map of Iran. As can see the Semirom is in the center of Iran.

\section{System Description}

\section{Load Demand}

The average electrical energy consumption PV-WindDiesel system in this study is equal $19.8 \mathrm{kWh} / \mathrm{d}$, and the peak load is estimated $1 \mathrm{~kW}$ belong to Semirom city that is obvious in Fig. 5.

Figure 6 shows the monthly wind speed of Semirom city. As can see in this fig this city has a relatively good wind speed to produce electrical energy.
Fig. 9 Schematic of hybrid system

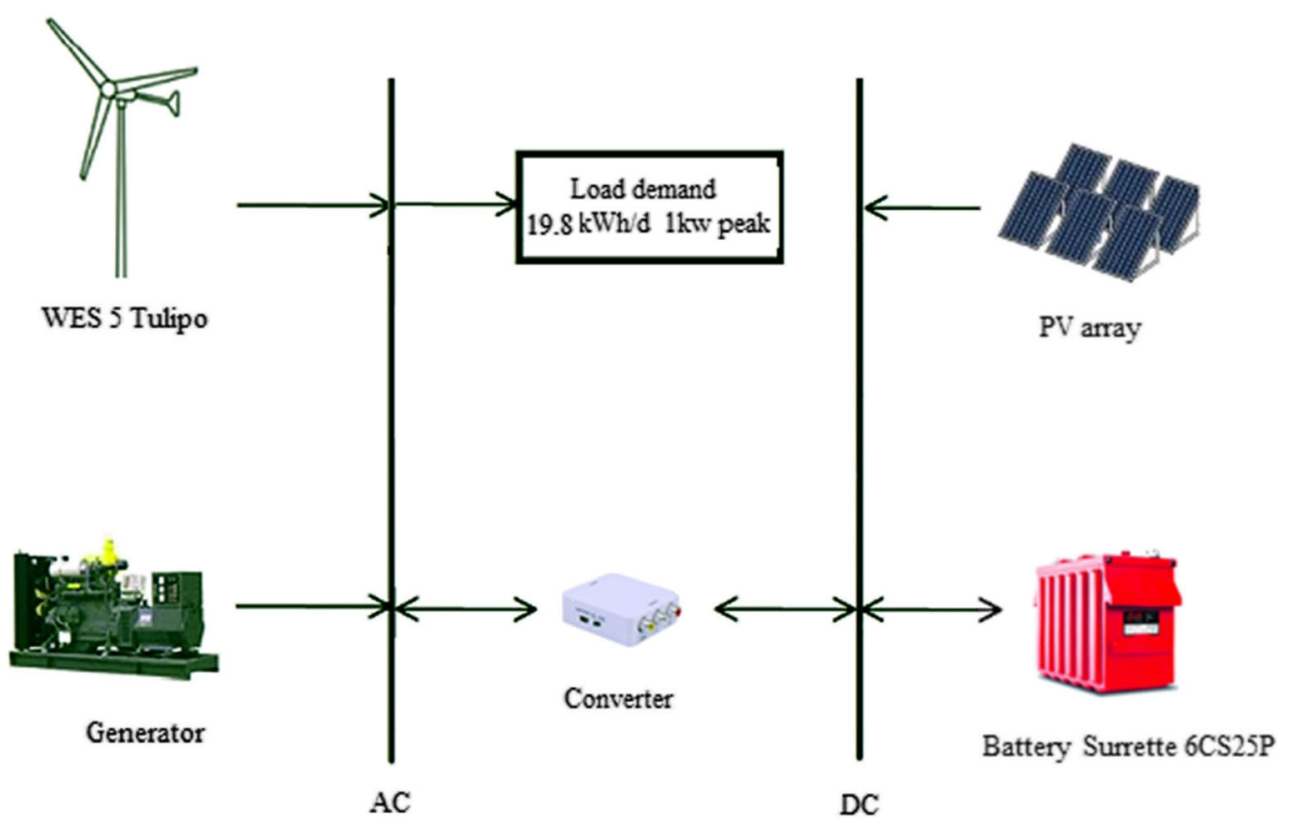


Table 2 Specifications of System architecture

\begin{tabular}{|c|c|c|c|c|c|}
\hline $\begin{array}{l}\text { PV } \\
\text { Array } \\
\mathrm{kW}\end{array}$ & $\begin{array}{l}\text { wind } \\
\text { turbine } \mathrm{kW}\end{array}$ & $\begin{array}{l}\text { Generator } \\
1 \mathrm{~kW}\end{array}$ & $\begin{array}{l}\text { Battery } \\
\mathrm{kW}\end{array}$ & $\begin{array}{l}\text { Inverter } \\
\mathrm{kW}\end{array}$ & $\begin{array}{l}\text { Rectifier } \\
\mathrm{kW}\end{array}$ \\
\hline 15 & $\begin{array}{r}2 \text { WES } 5 \\
\text { Tulipo }\end{array}$ & 1 & $\begin{array}{c}13,603 \text { Surrette } \\
6 \mathrm{CS} 25 \mathrm{P}\end{array}$ & 1 & 1 \\
\hline
\end{tabular}

Also, Fig. 7 shows the monthly solar radiation for Semirom city. Since this city placed in a good position to receive solar radiation, thus and it is clear in Fig. 5 Semirom city is capable of producing electrical energy from its solar potential.

Figure 8 shows the monthly wind speed and solar potential for Semirom city together.

\section{Technical-Economic Analysis of PV-Wind and Diesel System}

Figure 9 shows the schematic of a hybrid system that consisted of PV array, wind turbine WES 5 Tulipo model, generator, converter and battery 6CS25P model. In this study and as can see obviously in Fig. 9, the Load demand of PV-Wind-Diesel system is $19.8 \mathrm{kWh} / \mathrm{d}$ with $1 \mathrm{~kW}$ peak load. This system can produce the electrical energy by PV array to amount $27,035 \mathrm{kWh} / \mathrm{yr}$., Wind turbines $11,339 \mathrm{kWh} / \mathrm{yr}$. and with Generator to amount $976 \mathrm{kWh} / \mathrm{yr}$. This hybrid system in our study has a total electrical generation to equal $39,350 \mathrm{kWh} / \mathrm{yr}$.

The Homer software was used for technical-economic feasibility of the Wind-Solar-Diesel hybrid system. Initially, the data related to wind speed and solar radiation for the Semirom area was extracted using Iran's weather forecasting website in monthly and was entered to the Homer software. Then, required Information used to evaluate for Semirom area.

\section{Economic Analysis}

To calculate the total net present cost (NPC) of the system as follows annual cost can be calculated by the following equation [19]:

Table 3 Specifications of PV System architecture

\begin{tabular}{lllll}
\hline $\begin{array}{l}\text { Rated } \\
\text { capacity } \\
\mathrm{kW}\end{array}$ & $\begin{array}{l}\text { Mean } \\
\text { output kW }\end{array}$ & $\begin{array}{l}\text { Total } \\
\text { production } \\
\mathrm{kWh} / \mathrm{yr}\end{array}$ & $\begin{array}{l}\text { Capacity } \\
\text { factor } \%\end{array}$ & $\begin{array}{l}\text { Hours of } \\
\text { operation hr./yr. }\end{array}$ \\
\hline 15 & 3.09 & 27,035 & 20.6 & 4383 \\
\hline
\end{tabular}

Table 4 Specifications of wind turbine WES 5 Tulipo System architecture

\begin{tabular}{lllll}
\hline $\begin{array}{l}\text { Total rated } \\
\text { capacity kW }\end{array}$ & $\begin{array}{l}\text { Mean } \\
\text { output } \\
\mathrm{kW}\end{array}$ & $\begin{array}{l}\text { Total } \\
\text { production } \\
\mathrm{kWh} / \mathrm{yr}\end{array}$ & $\begin{array}{l}\text { Hours of } \\
\text { operation } \\
\mathrm{hr} . \mathrm{yr}\end{array}$ & $\begin{array}{l}\text { Wind } \\
\text { penetration } \\
\%\end{array}$ \\
\hline 5.00 & 1.29 & 11,339 & 7617 & 143 \\
\hline
\end{tabular}

$N P C=\frac{C t a n n}{C R F(i, n)}$

NPC is the total annual cost (in dollars), is the annual real interest rate (the discount rate), $\mathrm{N}$ is the number of years, $\operatorname{CRF}(i, n)$ is the capital recovery factor, and can be obtained by the following formula:

$C R F(i, n)=\frac{i(1+i)^{n}}{(1+i)^{n}-1}$

That in this equation $i$ the nominal interest rate and $n$ is the number of years. Energy cost balance can be calculated as follows:

$C O E=\frac{C t a n n}{\text { Eis }+ \text { Egrid }}$

Technical Specifications of System architecture considered and presented in Table 2 that are including PV Array, wind turbine, generator, battery, Inverter, and Rectifier. The Homer software was used to conduct a technical-economic analysis on the wind energy generation potential in order to obtain the inputs and output required for devising a ranking.

\section{PV Analysis}

Semirom city has good solar radiation, and the solar radiation ranges are from 2.88 to $7.78 \mathrm{kWh} / \mathrm{m} 2 / \mathrm{d}$. The maximum and minimum radiation occurs in June and December months, respectively. Also, the annual mean radiation is $5.32 \mathrm{kWh} /$ $\mathrm{m} 2 / \mathrm{d}$. Table 3 shows the specifications of the PV System architecture that for this system rated capacity is equal $15 \mathrm{~kW}$, mean output $3.09 \mathrm{~kW}$ and total production 27,035 $\mathrm{kWh} / \mathrm{yr}$. were obtained.

Table 5 Specifications of Generator 1System

\begin{tabular}{llll}
\hline $\begin{array}{l}\text { Hours of } \\
\text { operation hr./ }\end{array}$ & $\begin{array}{l}\text { Electrical } \\
\text { production } \\
\mathrm{kWh} . \mathrm{yr} .\end{array}$ & $\begin{array}{l}\text { Mean } \\
\text { electrical } \\
\text { output kW }\end{array}$ & $\begin{array}{l}\text { Fuel } \\
\text { consumption } \\
\mathrm{L} / \mathrm{yr}\end{array}$ \\
\hline 1558 & 976 & 0.626 & 633 \\
\hline
\end{tabular}


Table 6 Specifications of Battery System

\begin{tabular}{lllll}
\hline $\begin{array}{l}\text { String } \\
\text { size }\end{array}$ & $\begin{array}{l}\text { Bus } \\
\text { voltage } \\
\text { (V) }\end{array}$ & $\begin{array}{l}\text { Nominal } \\
\text { capacity kWh }\end{array}$ & $\begin{array}{l}\text { Batteries } \\
\mathrm{kWh} / \mathrm{yr}\end{array}$ & $\begin{array}{l}\text { annual throughput } \\
\mathrm{kWh} / \mathrm{yr} .\end{array}$ \\
\hline 9645 & 57,870 & 94,350 & 13,603 & 1491 \\
\hline
\end{tabular}

\section{Wind Turbine Analyses}

Semirom city has a range of 2.9 to $5.3 \mathrm{~m} / \mathrm{s}$ of wind speed that the maximum belongs to January and the minimum in November also average annual range is $4.04 \mathrm{~m} / \mathrm{s}$. Table 4 is specifications of wind turbine architecture and shows the total rated capacity, Mean output, and total production based $\mathrm{kW}$.

\section{Generator Analyses}

The specifications of Generator 1 System including hours of operation, electrical production, mean electrical output, and fuel consumption presented in Table 5. In this system, the amount of electrical production is equal to $976 \mathrm{kWh} / \mathrm{yr}$., and fuel consumption is equal to $633 \mathrm{~L} / \mathrm{yr}$.

\section{Battery Analyses}

The battery is one of the most important parts in the Hybrid system. As it is obvious in Table 6, for this system 13,603 Surrette 6CS25P model chosen with 94,350 kWh nominal capacity and $1491 \mathrm{kWh} / \mathrm{yr}$. annual throughput.

\section{Converter Analyses}

Table 7 shows the specifications of the considered converter for this system consisting of capacity, mean output, hours of operation and losses that is broke down in inverter and rectifier parts.

\section{Electrical Analyses}

Since electrical production by renewable energy (Hybrid system) is one of the main aims of this study, thus the most important part analyses for this system are related to electrical production - the breakdown of Specifications of the
Table 8 Specifications of Electrical System

\begin{tabular}{llll}
\hline $\begin{array}{l}\mathrm{PV} \text { array } \mathrm{kWh} / \\
\mathrm{yr}\end{array}$ & $\begin{array}{l}\text { Wind turbines } \mathrm{kWh} / \\
\mathrm{yr}\end{array}$ & $\begin{array}{l}\text { Generator } 1 \mathrm{kWh} / \\
\mathrm{yr}\end{array}$ & $\begin{array}{l}\text { Total kWh/ } \\
\mathrm{yr} .\end{array}$ \\
\hline 27,035 & 11,339 & 976 & 39,350 \\
\hline
\end{tabular}

electrical system presented in Table 8 that is including PV array, wind turbines and Generator 1 . The amount of electricity produced by $\mathrm{PV}$ is equal to $27,0.35 \mathrm{kWh} / \mathrm{yr}$., for the wind turbine is equal to $11,339 \mathrm{kWh} / \mathrm{yr}$. and for the generator is equal to $976 \mathrm{kWh} / \mathrm{yr}$., also this system has produced 39,350 $\mathrm{kWh} / \mathrm{yr}$. of electrical energy.

Figure 10 shows the monthly average electricity production by the PV, wind turbine and generator 1. As can see in this system the PV has a high percent share in electrical production and then wind turbine and generator respectively.

On the other hand, Table 9 shows the AC primary load, excess electricity and renewable fraction of electrical system. In this system AC primary load is equal 7, $921 \mathrm{kWh} / \mathrm{yr}$. and excess electricity is $30,781 \mathrm{kWh} / \mathrm{yr}$.

\section{Emission Analyses}

Since the emission of $\mathrm{CO}_{2}$ is more dangerous for environmental and human. Hence it can be reduced by various methods such as utilization renewable energy. To evaluate the $\mathrm{CO}_{2}$ emissions the following supporting equations has been presented:

$\mathrm{tCO}_{2}=3: 667 \times m_{f} \times \mathrm{HV}_{f} \times \mathrm{CEF}_{f} \times X_{C}$

In this equation $\mathrm{tCO}_{2}$ is Amount of CO2emissions, $m_{f}$ is Fuel quantity (Liter), $\mathrm{H} V_{f}$ is Fuel heating value $(\mathrm{MJ} / \mathrm{L}), \mathrm{CEF} F_{f}$ is Carbon emission factor (ton carbon/TJ) and $X_{C}$ is Oxidized carbon fraction. Table 10 shows the obtained data belong to the hybrid system. As it is clear carbon dioxide and Nitrogen oxides with 1668 and $36.7 \mathrm{~kg} / \mathrm{yr}$. has high rate of air pollution respectively.

Figure 11 shows summarize the annualized cash flow for this system, broken down by component for PVWind-diesel -battery and converter. The amount of

Table 7 Specifications of converter considered for this system

\begin{tabular}{|c|c|c|c|c|c|c|c|}
\hline \multicolumn{2}{|c|}{ Capacity kW } & \multicolumn{2}{|c|}{ Mean output kW } & \multicolumn{2}{|c|}{ Hours of operation hrs/yr } & \multicolumn{2}{|c|}{ Losses kWh/yr. } \\
\hline Inverter & Rectifier & Inverter & Rectifier & Inverter & Rectifier & Inverter & Rectifier \\
\hline 1.00 & 1.00 & 0.27 & 0.03 & 4634 & 2041 & 260 & 50 \\
\hline
\end{tabular}


Fig. 10 Monthly Average Electric Production of PV-windgenerator hybrid

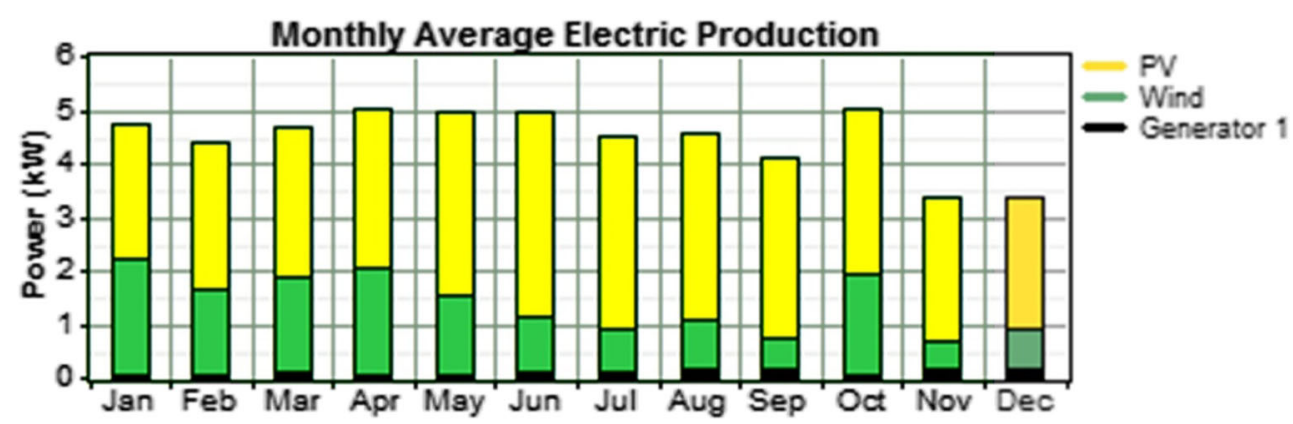

Table 9 Specifications of the electrical system

\begin{tabular}{llll}
\hline $\begin{array}{l}\text { AC primary load } \\
\mathrm{kWh} / \mathrm{yr}\end{array}$ & $\begin{array}{l}\text { Excess electricity } \\
\mathrm{kWh} / \mathrm{yr}\end{array}$ & $\begin{array}{l}\text { Renewable } \\
\text { fraction }\end{array}$ & $\begin{array}{l}\text { Unmet load } \\
\mathrm{kWh} / \mathrm{yr}\end{array}$ \\
\hline 7921 & 30,781 & 0.877 & 0.000000179 \\
\hline
\end{tabular}

Table 10 Emission analyses of hybrid system

\begin{tabular}{ll}
\hline Pollutant & Emissions $(\mathrm{kg} / \mathrm{yr})$ \\
\hline Carbon dioxide & 1668 \\
Carbon monoxide & 4.12 \\
Unburned hydrocarbons & 0.456 \\
Particulate matter & 0.31 \\
Sulfur dioxide & 3.35 \\
Nitrogen oxides & 36.7 \\
\hline
\end{tabular}

capital in this system is high more than other parts also as can see in this figure the maximum cost after the capital cost is for the replacement cost.

Table 11 shows a detailed breakdown of the NPC for PV-Wind-diesel-battery and converter hybrid system. The highest and lowest total lifetime cost of the system as belonging to the Surrette $6 \mathrm{CS} 25 \mathrm{P}$ and converter, which have values of US\$23,916 and US\$107 respectively, also this system presents a maximum regarding the cost of the system, which is US\$59,243.

\section{Conclusion}

Renewable energy has a significant role in reducing pollution environmental, global warming and achieving sustainable development. Also, renewable energy could be a reliable way to energy supply especially to electrical generation in the future. This research aims to perform a technical- economic feasibility study on the construction of PV-wind power plant in Semirom city in Esfahan province using HOMER software. Semirom city in this study has been investigated from the technicaleconomic point of view analysis on combined utilization of solar and wind power. This city has high potential in renewable energy, especially in solar and wind energy. In this study, using Homer software and regarding the potential of this city, for this hybrid system were selected a $15 \mathrm{~kW}$ PV array, 2 WES 5 Tulipo wind turbine, $1 \mathrm{~kW}$ generator, 13,603 Surrette 6CS25P model of battery, $1 \mathrm{~kW}$ Inverter and Rectifier. The technical analysis of this research showed that this city is capable of producing a remarkable amount of electrical energy using

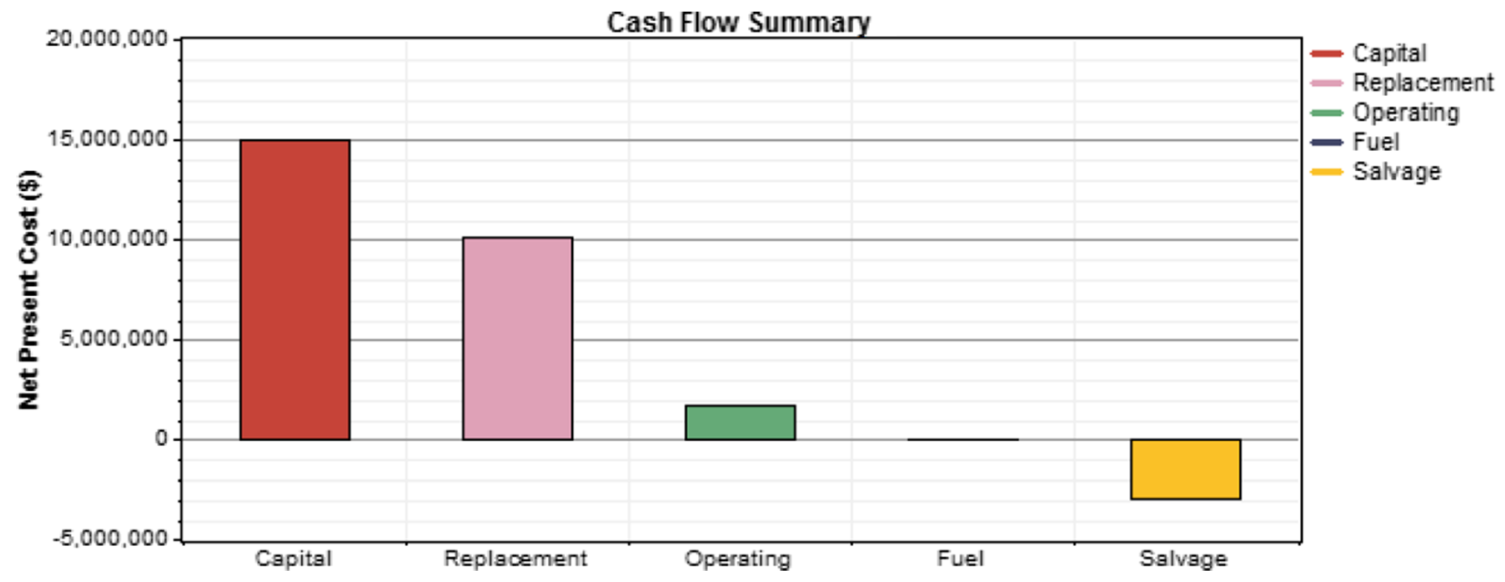

Fig. 11 Annualized cash flow summary by component for wind-diesel battery-converter- hybrid system 
Table 11 A detailed breakdown of the NPC for Wind-diesel-batteryconverter hybrid system

\begin{tabular}{|c|c|c|c|c|c|c|}
\hline Component & $\begin{array}{l}\text { Capital } \\
(\$)\end{array}$ & $\begin{array}{l}\text { Replacement } \\
\text { (\$) }\end{array}$ & $\begin{array}{l}\text { O\&M } \\
(\$)\end{array}$ & $\begin{array}{l}\text { Fuel } \\
(\$)\end{array}$ & $\begin{array}{l}\text { Salvage } \\
(\$)\end{array}$ & $\begin{array}{l}\text { Total } \\
\text { (\$) }\end{array}$ \\
\hline PV & 9000 & 2339 & 959 & 0 & -1311 & 10,987 \\
\hline $\begin{array}{l}\text { WES } 5 \\
\text { Tulipo }\end{array}$ & 10,000 & 3338 & 1278 & 0 & -621 & 13,995 \\
\hline Generator 1 & 1000 & 8066 & 398 & 1619 & -846 & 10,238 \\
\hline $\begin{array}{l}\text { Surrette } \\
\quad 6 \mathrm{CS} 25 \mathrm{P}\end{array}$ & 14,963 & 10,119 & 1738 & 0 & -2905 & 23,916 \\
\hline Converter & 70 & 29 & 13 & 0 & -5 & 107 \\
\hline
\end{tabular}

PV-Wind-Diesel hybrid system. Hence, a $15 \mathrm{~kW}$ PV array, 2 WES 5 Tulipo wind turbine, $1 \mathrm{~kW}$ generator, 13,603 Surrette 6CS25P model of battery, $1 \mathrm{~kW}$ Inverter and Rectifier are proper for the hybrid system. Also, the technical analysis for this city showed that this city could produce a significant amount of electrical energy by PV-wind turbine and diesel generator. The amount of electricity production by $\mathrm{PV}$ array is equal $27,035 \mathrm{kWh} /$ yr., Wind turbines $11,339 \mathrm{kWh} / \mathrm{yr}$. and Generator 1 is equal $976 \mathrm{kWh} / \mathrm{yr}$., also the total electrical generation of the hybrid system is $39,350 \mathrm{kWh} / \mathrm{yr}$. Overall, the calculated analyses showed that solar and wind energy potential for this city is sufficient to construct a PV-wind power plant and investment in this field has an economic justification.

\section{References}

1. Bagheri BS, Shirmohammadi R, Mahmoudi SMS, \& Rosen MA (2019) Optimization and comprehensive exergy-based analyses of a parallel flow double-effect water-lithium bromide absorption refrigeration system. Applied Thermal Engineering, 152, 643-653. https://doi.org/10.1016/j.applthermaleng.2019.02.105

2. Besarati SM, Padilla RV, Goswami DY, Stefanakos E (2013) The potential of harnessing solar radiation in Iran: Generating solar maps and viability study of PV power plants. Renew Energy 53: 193-199

3. Bogdanov D, Breyer C (2016) North-East Asian Super Grid for 100\% Renewable Energy supply: Optimal mix of energy technologies for electricity, gas and heat supply options. Energy Convers Manag 112:176-190

4. Bugaje I (2006) Renewable energy for sustainable development in Africa: a review. Renew Sust Energ Rev 10(6):603-612

5. Chauhan RK, Chauhan K (2019) Management of renewable energy source and battery bank for power losses optimization. In Smart Power Distribution Systems (pp. 299-320): Elsevier.

6. Chu S, Cui Y, Liu N (2017) The path towards sustainable energy. Nat Mater 16(1):16

7. Davarpanah, A. (2018). A feasible visual investigation for associative foam $>\backslash$ polymer injectivity performances in the oil recovery enhancement. European Polymer Journal, 105, 405-411. https:// doi.org/10.1016/j.eurpolymj.2018.06.017
8. Davarpanah A (2018). The feasible visual laboratory investigation of formate fluids on the rheological properties of a shale formation. Int. J Environ Sci Technol https://doi.org/10.1007/s13762-018$1877-6$

9. Davarpanah A, Akbari E, Doudman-Kushki M, Ketabi H, \& Hemmati M (2019) Simultaneous feasible injectivity of foam and hydrolyzed polyacrylamide to optimize the oil recovery enhancement. Energy Explor Exploit 37(1):44-59.

10. Davarpanah A, \& Mirshekari B (2018). Experimental study and field application of appropriate selective calculation methods in gas lift design. Pet Research 3(3):239-247. https://doi.org/10. 1016/j.ptlrs.2018.03.005

11. Davarpanah A, Razmjoo A, \& Mirshekari B (2018) An overview of management, recycling, and wasting disposal in the drilling operation of oil and gas wells in Iran. Cogent Environmental Science, 4(1): $1-7$

12. Davarpanah A, Shirmohammadi R, \& Mirshekari B (2019) Experimental evaluation of polymer-enhanced foam transportation on the foam stabilization in the porous media. Int $\mathrm{J}$ Environ Sci Technol https://doi.org/10.1007/s13762-019-02280-z

13. Davarpanah A, Zarei M, Valizadeh K, \& Mirshekari B (2018) CFD design and simulation of ethylene dichloride (EDC) thermal cracking reactor. Energy Sources, Part A: Recovery, Utilization, and Environmental Effects, 1-15

14. Dincer F (2011) The analysis on photovoltaic electricity generation status, potential and policies of the leading countries in solar energy. Renew Sust Energ Rev 15(1):713-720

15. Dincer I (2000) Renewable energy and sustainable development: a crucial review. Renew Sust Energ Rev 4(2):157-175

16. Ebadati A, Akbari E, \& Davarpanah A (2018) An experimental study of alternative hot water alternating gas injection in a fractured model. Energy Exploration \& Exploitation, 0144598718815247

17. Ehyaei M, Farshin B (2017) Optimization of photovoltaic thermal (PV/T) hybrid collectors by genetic algorithm in Iran's residential areas

18. Hadian S, Madani K (2015) A system of systems approach to energy sustainability assessment: Are all renewables really green? Ecol Indic 52:194-206

19. Hafez O, Bhattacharya $\mathrm{K}$ (2012) Optimal planning and design of a renewable energy based supply system for microgrids. Renew Energy 45:7-15

20. Hosseini SE, Andwari AM, Wahid MA, Bagheri G (2013) A review on green energy potentials in Iran. Renew Sust Energ Rev 27:533545

21. Jahangiri, M., Khosravi, A., Raiesi, H. A., \& Mostafaeipour, A. (n.d.) Analysis of Standalone PV-Based Hybrid Systems for Power Generation in Rural Area.

22. Khare V, Nema S, Baredar P (2013) Status of solar wind renewable energy in India. Renew Sust Energ Rev 27:1-10

23. Khojasteh D, Khojasteh D, Kamali R, Beyene A, Iglesias G (2017) Assessment of renewable energy resources in Iran; with a focus on wave and tidal energy. Renew Sust Energ Rev

24. Lund H (2007) Renewable energy strategies for sustainable development. Energy 32(6):912-919

25. Mardani A, Jusoh A, Zavadskas E, Cavallaro F, Khalifah Z (2015) Sustainable and renewable energy: An overview of the application of multiple criteria decision making techniques and approaches. Sustainability 7(10):13,947-13,984

26. Mazarei M, Davarpanah A, Ebadati A, \& Mirshekari B (2019) The feasibility analysis of underground gas storage during an integration of improved condensate recovery processes. J. Pet Explor Prod Technol 9(1):397-408. https://doi.org/10.1007/s13202-018-0470-3

27. Mostafaeipour A, Jadidi M, Mohammadi K, Sedaghat A (2014) An analysis of wind energy potential and economic evaluation in Zahedan, Iran. Renew Sust Energ Rev 30:641-650 
28. Najafi G, Ghobadian B, Mamat R, Yusaf T, Azmi W (2015) Solar energy in Iran: Current state and outlook. Renew Sust Energ Rev 49:931-942

29. Ocal O, Aslan A (2013) Renewable energy consumption-economic growth nexus in Turkey. Renew Sust Energ Rev 28:494-499

30. Qolipour M, Mostafaeipour A, Tousi OM (2017) Techno-economic feasibility of a photovoltaic-wind power plant construction for electric and hydrogen production: A case study. Renew Sust Energ Rev $78: 113-123$

31. Razmjoo A, \& Davarpanah A (2019) Developing various hybrid energy systems for residential application as an appropriate and reliable way to achieve Energy sustainability. J.E.S, Part A: Recovery Utilization, and Effects E. 41(10):1180-1193

32. Razmjoo A, Shirmohammadi R, Davarpanah A, Pourfayaz F, \& Aslani A (2019) Stand-alone hybrid energy systems for remote area power generation. Energy Reports, 5, 231-241

33. Razmjoo A, Heibati S, Ghadimi M, Qolipour M, Nasab J (2016) Using Angstrom-Prescott (AP) Method for Estimating Monthly Global Solar Radiation in Kashan. J Fundam Renewable Energy Appl 6:214. https://doi.org/10.4172/20904541.1000214

34. Razmjoo A, Qolipour M, Shirmohammadi R, Heibati SM, Faraji I (2017b) Techno-economic evaluation of standalone hybrid solarwind systems for small residential districts in the central desert of Iran. Environ Prog Sustain Energy 36(4):1194-1207

35. Saeidi D, Mirhosseini M, Sedaghat A, Mostafaeipour A (2011) Feasibility study of wind energy potential in two provinces of
Iran: North and South Khorasan. Renew Sust Energ Rev 15(8): 3558-3569

36. Shirmohammadi R, Soltanieh M, Romeo LM (2018) Thermoeconomic analysis and optimization of post-combustion $\mathrm{CO} 2$ recovery unit utilizing absorption refrigeration system for a natural-gas-fired power plant. Environ Prog Sustain Energy 37(3): 1075-1084. https://doi.org/10.1002/ep.12866

37. Tofigh AA, Abedian M (2016) Analysis of energy status in Iran for designing sustainable energy roadmap. Renew Sust Energ Rev 57: 1296-1306

38. Valizadeh K, \& Davarpanah A (2019) Design and construction of a micro-photo bioreactor in order to dairy wastewater treatment by micro-algae: parametric study. Energy Sources, Part A: Recovery, Utilization, and Environmental Effects 1-14

39. Verrastro F, Ladislaw S (2007) Providing energy security in an interdependent world. Wash Q 30(4):95-104

40. Zhou W, Lou C, Li Z, Lu L, Yang H (2010) Current status of research on optimum sizing of stand-alone hybrid solar-wind power generation systems. Appl Energy 87(2):380-389

Publisher's Note Springer Nature remains neutral with regard to jurisdictional claims in published maps and institutional affiliations. 